\author{
(online) $=$ ISSN $2285-3642$ \\ ISSN-L = $2285-3642$ \\ Journal of Economic Development, Environment and People \\ Volume 6, Issue 1, 2017 \\ URL: http://iedep.spiruharet.ro \\ e-mail: office jedep@spiruharet.ro
}

\title{
The Organizational Leaders Administrative Justice and its Impact on Employees' Career Performance
}

\section{(A practical study on private University Colleges of Economic Sciences Al-Ma'mun in Baghdad)}

Drd. Zaid Yaseen Saud Al-Dulaimi ${ }^{1}$, Dr. Rabeea Yaseen Saud Al-Dulaimi ${ }^{2}$, Drd. Marwan Sabah Hasan

\author{
Al-Tekreeti ${ }^{3}$ and Drd. Fedaa Abd Almajid Sabbar Al-Araji ${ }^{4}$ \\ ${ }^{1}$ Bucharest University of Economic Studies (ASE)- Faculty of Marketing \\ ${ }^{2,3}$ Al Iraqia University- Faculty of Economics and Business Administration \\ ${ }^{4}$ University of Craiova- Faculty of Economics and Business Administration
}

\begin{abstract}
The goal of this study is to help us to know the degree of Organizational Justice practiced by the administrative leaders in Baghdad for Economic Sciences and of Al-Ma'mun private university colleges in Baghdad and its relationship to the employees' work or Career Performance. In order to achieve this goal, the study will seek to answer the following questions:

- What is the degree of Organizational Justice practiced by the administrative leaders in the above mentioned colleges from the employees' point of view?

- What is the level of Career Performance of employees from the point of view of their leaders?

The study group consists of administrative leaders and department heads of the institution under discussion. Researchers will use a questionnaire for data collection and it will include, the responder's demographic information, the measuring tool for the Organizational Justice practiced by the administrative leaders, the measurement of Career Performance of their employees. The instruments of the study were verifiedby informing the referees jurisdiction, and by the appropriateness of using the test method and the test itself. To respond to the questions, researchers will use arithmetic averages, standard deviations and Pearson Linklabs.
\end{abstract}

\footnotetext{
${ }^{1}$ Tel. +40723095888; E-mail address: zaidyaseen610@yahoo.com

${ }^{2}$ Tel. +009647810207985; E-mail address: rbsod 2006@yahoo.com

${ }^{3}$ Tel. +009647904813085; E-mail address: $\underline{\text { ms monshed@yahoo.com }}$

${ }^{4}$ Tel. +40721109557; E-mail address: fdaasabbar@yahoo.com
} 


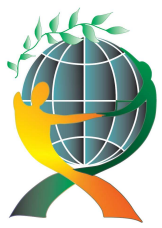

\author{
(online) $=$ ISSN $2285-3642$ \\ ISSN-L = $2285-3642$ \\ Journal of Economic Development, Environment and People \\ Volume 6, Issue 1, 2017 \\ URL: http://iedep.spiruharet.ro \\ e-mail: office jedep@spiruharet.ro
}

Keywords: Organizational Justice, Career Performance, Employees' satisfaction

JEL Codes: $M 31$

\title{
1. Introduction
}

All organizations, whether producers of goods or services providers, are affected by the evolution of technology and the rapid changes in the world, and these changes are reflected in the education system, in all its areas. No leader can ignore these evolving conditions, but he or she must interact with these changes and meet the challenges of the institution to find a new valid working environment and to enable the educational institution adapt to rapid changes in economic environment the success of these educational institutions deeply depends on the efficiency and activity of its members, to increase the productivity.

These changes and developments in science and technology has accelerated the emergence of the concept of a new management style,followed by the educational leader in his/her leadership to his/her subordinates within, the broader organizational process of building within the institution. Organizational justice requires special attention to enhance the fairness and equality for rights and the benefits to individuals and groups, participation in the system of the regulatory of the work enterprise and to raise the level of functionality and access in the institution to achieve its goals and objectives in the best manner, in an atmosphere of harmony and adaptation positive harmony and harmonizing to install and to enhance efficiency and effectiveness. Organizational justice is based on the comparing process done by an individual between him/herself with his/her colleagues from the same career position within the Organization in terms of the amount of effort and the amount of the wage. An employee will be motivated by work if he/she feels some sort of justice compared with his/her colleagues, but on the other hand an employee will start in reducing the effort both in the amount of production and its quality when he or she feels the injustice which in turn will lead him/her to either skip or leave the work and to seek another work. (Himshry, 2001)

In the light of that (AlTaweel, 2001) emphasized the need to develop a policy governing ethical behaviour that is supposed to abide by the administrative leader in an effort to ensure that the conduct of the two types of reflecting the dignity of the profession, honor, and also to maintain the objectivity and impartiality in the application of the regulations and instructions, and the need to respect the dignity and value of each employee, and giving every employee his/her right. Respect for laws and regulations and instructions of adherence to the standards of high moral and affiliation sincerity and observance of the principles of democracy, a lack of hiding to any evidence or information might be of assistance in the realization of justice.

In addition, not to allowed any pressure that would affect the principles of justice and equality or freedom of expression, and commitment to the use of human and material resources and reducing of effectiveness and efficiency. 


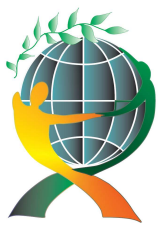

\author{
(online) $=$ ISSN $2285-3642$ \\ ISSN-L = $2285-3642$ \\ Journal of Economic Development, Environment and People \\ Volume 6, Issue 1, 2017 \\ URL: $\underline{\text { http://iedep.spiruharet.ro }}$ \\ e-mail: office jedep@spiruharet.ro
}

\title{
2. Research Methodology
}

\subsection{Research Problem}

The administrative leader of an educational organization, like any other administrative leader in any other organizations, can not be able to achieve success in his/her work, and to achieve the goals of the organization, unless he/she shows a real commitment to the administrative principles known in the forefront of dealing with his/her subordinates and his staff on the basis of justice and equality. This principle has also been confirmed by all administrative schools without exception, who created his own way in practice administrative morality as "organizational justice".

Theme investigated is determined by the following questions:

- Is there any actual practice of the organizational justice by the administrative leaders in the discussed colleges able to achieve an improvement in the career performance?

- What is the level of the efficiency of the workers from the point of view of their leaders?

\subsection{Research Objectives}

The study aimed to know the degree of the organizational justice exercised by the administrative staff leaders in educational institution in Baghdad under discussion and their relationship with the functionality of workers and faith and trust they have in their administrative leaders through the achievement of the following objectives:

- The achievement of organizational justice when exercising administrative leadership in these colleges in terms of employees.

- Improving career performance in above mentioned colleges by applying the concept of organizational justice by the leaders.

- Raising the degree of confidence between the administrative leaders in colleges, on the one hand and with the employees on the other hand.

\subsection{The Research Importance}

The importance of the study is that it seeks to investigate the views of those working in educational institutions on the concept of organizational justice and its relevance in work organization. As the efficiency of the human element depends on the availability of a proper work environment that takes into account his/her considerations, emotions and needs, where there is a climate established by a regulatory framework, this will help the development of the administrative system and increase its effectiveness and contribute to improve the level of performance of their personals, and reduce its operational costs. It is to be hoped that the results of this research will be of a great help to the administrative leaders in discussed colleges through knowing the degree of their exercise of organizational justice. It is also to be hoped that it will help university librairies, as well as source of informations for researchers and all those interested in the variables of organizational behaviour in business organizations to conduct further studies and research in this area.

\subsection{Research Hypothesis}

By analyzing responses to the questions and the various arising problems, researchers admit following assumptions: 


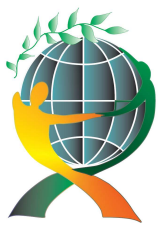

\author{
(online) $=$ ISSN $2285-3642$ \\ ISSN-L = $2285-3642$ \\ Journal of Economic Development, Environment and People \\ Volume 6, Issue 1, 2017 \\ URL: http://iedep.spiruharet.ro \\ e-mail: office jedep@spiruharet.ro
}

The first main hypothesis: there is a statistical relationship $(0.05 \geq \alpha)$ of the organizational justice variables for estimating administrative leaders and the career performance in the discussed colleges in Baghdad.

Flowing from this first main hypothesis derived following Sub-hypotheses:

- The first Sub-hypothesis: there is a relationship of statistical significance $(0.05 \geq \alpha)$ indicating the exercise of administrative leaders for procedural justice and in career performance in the discussed colleges.

- The second Sub-hypothesis: there is a relationship of statistical significance $(0.05 \geq \alpha)$ indicating the exercise of administrative leaders for interactive justice and in career performance in the discussed colleges.

- The third Sub-hypothesis: there is a relationship of statistical significance $(0.05 \geq \alpha)$ indicating the exercise of administrative leaders for procedural justice and the level of work performance in the discussed colleges.

- The fourth Sub-hypothesis: there is a relationship of statistical significance $(0.05 \geq \boldsymbol{\alpha})$ indicating the exercise of administrative leaders for procedural justice and the level of work performance in the discussed colleges.

- The second main hypothesis: there is a relationship of statistical significance $(0.05 \geq \alpha)$ indicating the exercise of administrative leaders for procedural justice and the four dimensions of work performance of the workers in the discussed colleges.

Flowing from this first main hypothesis the following Sub-hypotheses came:

- The first Sub-hypothesis: there is a relationship of statistical significance $(0.05 \geq \alpha)$ indicating the exercise of administrative leaders for procedural justice after the state of creativity is achieved by an employee in the discussed colleges.

- The second Sub-hypothesis: there is a relationship of statistical significance $(0.05 \geq \alpha)$ indicating the exercise of administrative leaders for procedural justice after the state of sufficiency and full activity is achieved by an employee in the discussed colleges.

- The third Sub-hypothesis: there is a relationship of statistical significance $(0.05 \geq \alpha)$ indicating the exercise of administrative leaders for procedural justice after the process of enhancing carrier performance for employees in the discussed colleges.

- The fourth Sub-hypothesis: there is a relationship of statistical significance $(0.05 \geq \boldsymbol{\alpha})$ indicating the exercise of administrative leaders for procedural justice after the state of completion of carrier performance is achieved for the employees in the discussed colleges. 

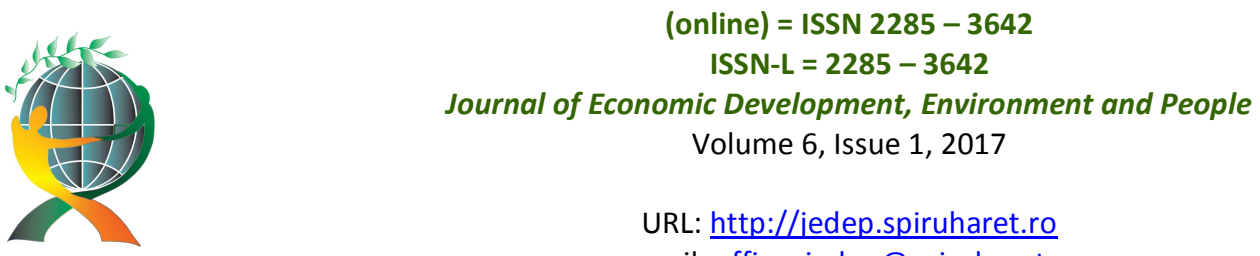

URL: http://iedep.spiruharet.ro

e-mail: office jedep@spiruharet.ro

\subsection{The Default Research Model}

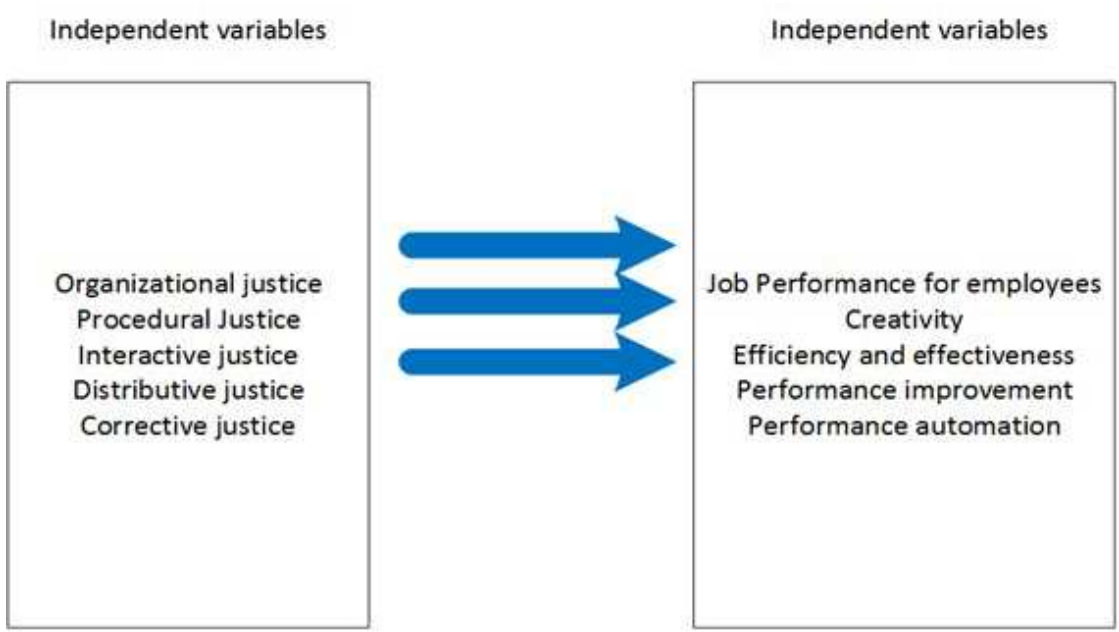

Fig. 1: Research model.

\subsection{Procedural Definitions for the Research Variables}

The following are the procedural definitions:

a. Administrative Leaders: rushing Al-Qarioti (2000) as the leaders who influence on a group of individuals or a group, earning their voluntarily cooperation under their leadership and prospering homogeneity and persuade them to achieve their goals.

b. The Organizational Justice: as the outcome of the agreement between the efforts made and obtained outcomes, in a way that contributes to achieving the desired objectives of the Organization. (Byars and Rue, 1997).

- Distributive Justice: as the equitable distribution of the sources of the organizational opportunities, as individuals are subjected to the assessment of the results of their work in accordance with the rule of distributive justice based on the principle of equality (Khalipha, 1997)

- Procedural Justice: the feeling of the positive sense of justice and institutional procedures used in determining the output, (Niehoff \& Moorman, 1993)

- Interactive Justice: the extent of a sense of justice the workers may feel when they are subjected to official procedures or when they are aware the reason behind those procedures

- Corrective Justice: is that justice which includes the operations, specific procedures and systems ensuring that the rights of workers and their performance levels are rectified in a fair and impartial manner, to secure their stability and career development (Katawna, 2003).

c. Job Performance: as a set of behaviours that evaluates performance in their job, his/her responsibilities accomplishment, and it also includes the quality of performance and efficiency of implementation and the technical expertise that a job requires, as well as the communication and interaction with the rest of the members of the organization and the acceptance of the new tasks, 


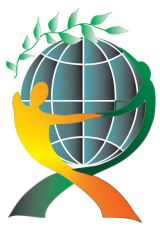

\author{
(online) $=$ ISSN $2285-3642$ \\ ISSN-L = $2285-3642$ \\ Journal of Economic Development, Environment and People \\ Volume 6, Issue 1, 2017 \\ URL: http://iedep.spiruharet.ro \\ e-mail: office jedep@spiruharet.ro
}

creativity and commitment to the administrative aspects of the work, and to respond to them with care and effectiveness. (Sizlaqi, Wallace, 1991):

- Creativity: is a combination of capacity-building and preparations as well as the personal characteristics, which if found in an appropriate environment could lead the mental processes to reach genuine and useful achievements to both previous individual or expertise and the institution's or the community or the world if the results reach the level of creativity breakthroughs in one of the fields of human life. (Bin Antar Abdul Rahman, 2008, 148)

- Efficiency and Effectiveness: efficiency is defined as: the extent to which the objectives achieved and therefore is measured in terms of the relationship between the results achieved and goals, while effectiveness means the ability to minimize the levels of use of resources without prejudice to the goals measured in terms of the relationship between the results determinants, or results and resources used. (Marchesnag, 1988:27)

- Improve Performance: the use of all available resources to improve output and productivity of the operations and the complementarity between the right technology which employs capital and the best way to improve the performance and the balance of a set of elements operating in the quality and productivity, technology and cost the balance of these elements the expectations and needs of the stakeholders in the enterprise has underlined into account, this is called acumilitative curriculum" administrating overall improvement" (lavender, 1999: 11)

- Performance Automation: using the computer and devices based on the processors or software in various industrial and commercial sectors and service in order to ensure the conduct of the proceedings and work will be in the most accurate, safe way, and with the least errors (Zaareb, 2008:18)

\title{
3. Theoretical Framework
}

\subsection{Organizational Justice}

\subsubsection{The Concept of Organizational Justice}

It takes its roots from the theory of equality (Equity Theory) of Adams (Adams 1965) which is based on justice and equality in the treatment of the individual in his/her career, as an individual believes that the main factor for the process of assessing his/her work performance efforts and the satisfaction is the degree of justice and equality, or the lack of justice and equality that an the individual is aware of, and the evident of this theory in job satisfaction when individuals and workers feel that organization's rewards like salary and appreciation evenly distributed among them, in accordance with their personal functional professionalism.

As defined be (Assaf, 2005): the proportion of inputs (work effort) to output (salary or income or the recognition and appreciation) compared with others, justice include three steps: (evaluation, comparison, behaviour), justice is obvious in the job satisfaction for workers when he/she (staff member) feels that the rewards of the Organization (salary and the recognition and appreciation), evenly distributed among them, in accordance with their capabilities (i.e. the degree of entitlement to each and every one of them). 


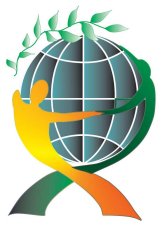

\author{
(online) $=$ ISSN $2285-3642$ \\ ISSN-L = $2285-3642$ \\ Journal of Economic Development, Environment and People \\ Volume 6, Issue 1, 2017 \\ URL: http://iedep.spiruharet.ro \\ e-mail: office jedep@spiruharet.ro
}

Thus, the organizational justice is a sense of conscious value directed towards the completion of the institutional Justice reassuring the staff in the organization rights functional gains, despite their disagreement in the level of awareness comparisons.

\title{
3.1.2. Types of Organizational Justice
}

Almaghreby 1994, said that there were four types of Organizational Justice concerning any organization or institution, they are distributional justice, corrective justice, procedural justice, and interactive justice, and they are as follows:

a. Distributional Justice: The fairness of the outputs obtained by the staff member. As defined by Khalifa, (Khalifa 1997) as the equitable distribution of the sources of the organizational opportunities, as subject to the assessment of the results of their work in accordance with the rule of distributive justice based on the principle of equality. Koopman (Koopmann, 2003) classified distributive justice in three types:

- Equity - it is based on the position of the staff member to work according to the extent of its contribution and productivity and his/her efforts and the need for action, who carries a full time does not equate with the part-time and, in the case of equal remuneration and proceeds, it is a breach of the rule of equity.

- Equality - it is based on the principle of public revenues regardless the concepts of race, color, sex, and all should be on the same level of distribution on the basis of knowledge and skill and productivity.

- The Need - it is need to distribute the proceeds according to the level and the large need for the employee for his or her spouse. In other words, the needs of an employee who has a family with three children will be higher than those of a family with one child, while the other conditions are equal.

b. Procedural justice: it is the positive sense of justice that determines the institutional procedures usually applied (Niehoff \& Moorman, 1993). Koopmann noted (Koopmann, 2003) that there are two types of procedural justice:

- Systematic Justice - it is the use of a clear methodology of the procedures used in taking distributive decisions, according to the basic rules of procedural justice.

- Informational Justice - it is justification for the procedures of a decision to provide clear information to workers of the beneficiaries of the output regarding the decision taken at the distribution procedures.

The extent to which a sense of the workers of the justice of treatment received by the working group, when applied by some official proceedings, or to know the reasons for its application of those procedures, (Niehoff and Moorman, 1993).

Altaheeh, Mohamed, 2003 noted that the realization of the workers' interactive justice depends on four factors:

- the extent of clear justifications for the decisions taken.

- the extent insofar as there is sincerity and frankness when officially discussing with the workers.

- official's respect for the workers.

- official's commitment of ethics dealing with the workers. 


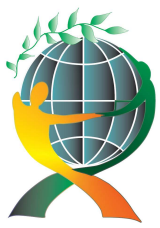

\author{
(online) $=$ ISSN $2285-3642$ \\ ISSN-L = $2285-3642$ \\ Journal of Economic Development, Environment and People \\ Volume 6, Issue 1, 2017 \\ URL: http://iedep.spiruharet.ro \\ e-mail: office jedep@spiruharet.ro
}

c. Evaluation Justice - is that form of justice which includes the operations, procedures, and specific systems ensuring that the rights of workers and levels of their performance be rectified in a fair and impartial manner, to secure stability and career development (Alqatawna, 2003). It is for the justice system should be a system of assessing the performance of workers, which could affect the performance level as follows:

- To give a chance to the individuals to highlight their voluntary activities.

- Inclusion of the weights in the system of performance evaluation for the volunteer activities.

- Pressing the voluntary activities to use when needed.

- The balance between official activities and voluntary activities.

Performance evaluation is important in order to ensure the continued success of the institution enables it to keep those employees with the outstanding performance and also to improve those with the weak performance, and the importance of the results of the performance evaluation of the influence the behavior of workers.

\title{
3.2. Functional Performance
}

\subsubsection{The Concept of Functional Performance}

As defined by Arnold Publick (Arnold \& Publick, 2003) career performance is "the volume of the positive impact of individuals toward their work in institutions in which they work".

And also defined (Walas and Sizlaqi 1991) as a set of patterns of administrative behaviour with a relevant relationship expressing the employee's performance of his/her tasks and responsibilities. They include the quality of performance, efficiency of implementation and technical expertise required in function, as well as the communication and interaction with the rest of the members of the organization, and the acceptance of the new tasks, creativity, and commitment to the administrative aspects of the work and seek to respond to them with care and effectiveness.

Was defined (AlYazageen: 2003) as the activity by which the individual will be able to accomplish the tasks and objectives and obligations planned, diligently, and implementation, as is a decree to job description. Also defined by Rao (Rao, 2004) as what an individual was expected to do within the specific framework. In the light of we already said, the Functional Performance can be defined as the functionality of carrying the burdens of the requirements, the duties and responsibilities of the function of the Administrative Section or the administrative unit to fully accomplish the tasks entrusted to him/her to the.

There is a group of factors that could affect the Functional Performance of an organization as was identified by Abdul Mohsen, in 2002, including the following:

- The volume of work that might affect the functionality of the workers in an organization dealing with the nature of the presence of a large volume of work. The needs of the administrative unit had more or less on some of the units within an organization.

- The backlog or deferred in a manner more than the usual could cause the most cursory higher rate of production. Such a hurry or speed to accomplish generates a decline in the quality of the final product. While the shortage of some available works generate a decrease in the rate of production. 


\author{
(online) $=$ ISSN $2285-3642$ \\ ISSN-L = 2285 - 3642 \\ Journal of Economic Development, Environment and People \\ Volume 6, Issue 1, 2017
}

URL: http://jedep.spiruharet.ro

e-mail: office jedep@spiruharet.ro

- Organizational and procedural structuring have a direct impact on the functionality, because production rate depends on several factors including the appropriateness of the organizational as well as procedural arrangements. The organizational amendment that changes the flow of work clamors, usually consequents a change in the rate of achievement, and a shortcut in the work steps in the process of reducing the resources required to end the work.

- Technical factors: the follow-up and continuity in the introduction of modern technology, evaluation equipment, to both the hardware and software, because the performance of the employees set by level of the available technology and quality.

\title{
4. Scientific Framework
}

\subsection{Description of the Sample Study}

The study sample included the discussed colleges where a distribution of 40 questionnaire form for professors and staff, 34 forms have been retrieved to measure the organizational justice and its impact on the functionality.

\subsection{The Diagnosis of the Research Variables}

The calculation of the standard deviations responses to special sample organizational justice:

\begin{tabular}{|c|c|c|c|c|}
\hline & $\begin{array}{c}\text { Dimensions of } \\
\text { Organizational Justice }\end{array}$ & $\begin{array}{c}\text { Expected } \\
\text { Arithmetic Mean }\end{array}$ & $\begin{array}{c}\text { The standard } \\
\text { deviation }\end{array}$ & $\begin{array}{l}\text { The average } \\
\text { standard }\end{array}$ \\
\hline \multicolumn{5}{|l|}{ Procedural Justice } \\
\hline 1 & & 3.6471 & 0.88360 & Moderate \\
\hline 2 & & 3.5294 & 0.74814 & Moderate \\
\hline 3 & & 3.5882 & 0.85697 & Moderate \\
\hline 4 & & 3.5882 & 1.07640 & Moderate \\
\hline The average & & 3.5882 & 0.67667 & Moderate \\
\hline \multicolumn{5}{|l|}{ Interactive Justice } \\
\hline 1 & & 3.5588 & 0.89413 & Moderate \\
\hline 2 & & 3.6765 & 1.00666 & Moderate \\
\hline 3 & & 3.9706 & 0.67354 & Moderate \\
\hline 4 & & 3.9706 & 0.83431 & Moderate \\
\hline The average & & 3.7941 & 0.65271 & Moderate \\
\hline \multicolumn{5}{|l|}{ Distributive Justice } \\
\hline 1 & & 3.5000 & 1.02247 & Moderate \\
\hline 2 & & 3.5294 & 1.07971 & Moderate \\
\hline 3 & & 3.4118 & 0.82085 & Moderate \\
\hline 4 & & 3.7353 & 0.93124 & Moderate \\
\hline The average & & 3.5441 & 0.73203 & Moderate \\
\hline \multicolumn{5}{|l|}{ Corrective Justice } \\
\hline 1 & & 3.5294 & 0.89562 & Moderate \\
\hline 2 & & 3.6765 & 0.94454 & Moderate \\
\hline 3 & & 3.3824 & 1.04489 & Moderate \\
\hline 4 & & 3.2941 & 0.79884 & Moderate \\
\hline The average & & 3.4706 & 0.66505 & Moderate \\
\hline $\begin{array}{l}\text { The main average of the } \\
\text { organizational Justice }\end{array}$ & & 3.5993 & 0.48950 & Moderate \\
\hline
\end{tabular}




\author{
(online) $=$ ISSN $2285-3642$ \\ ISSN-L = $2285-3642$ \\ Journal of Economic Development, Environment and People \\ Volume 6, Issue 1, 2017
}

URL: http://iedep.spiruharet.ro

e-mail: office jedep@spiruharet.ro

Recalling the results of the Table No. 1, results that organizational justice has got the SMA in the amount of USD (3.5993) and the standard deviations (0.48950) which indicates the homogeneity of the sample answers about the value of covariance level where dimensions came after interactive justice is more homogenous in terms of staff answers as he got the SMA of (3.7941), and a standard deviation of (0.65271), the direction of this dimension is (OK) and to the level of the average (moderate), while at the level of the paragraphs, paragraph No. (3), in this dimension which are (the deanship encourages teamwork among staff) is more homogenous, where it got the medium (3.9706) with the standard deviations of (0.67354) and the direction of this paragraph is (OK) with the average level of (moderate), the general direction of the organizational justice is (OK) and at the average level of (moderate), therefore the order of the dimensions of the organizational justice would be indicated in the table no. 2 .

Table 2. The arrangement of the dimensions of the organizational justice among a research sample

\begin{tabular}{|c|c|c|c|c|}
\hline Ranking & Organizational Justice & Arithmetic Mean & $\begin{array}{c}\text { The standard } \\
\text { Deviation }\end{array}$ & $\begin{array}{c}\text { Overall } \\
\text { Direction }\end{array}$ \\
\hline First & Procedural Justice & 3.7941 & 0.65271 & Agree \\
\hline Second & Interactive Justice & 3.4706 & 0.66505 & Agree \\
\hline Thirdly & Distributive Justice & 3.5882 & 0.67667 & Agree \\
\hline Fourthly & Corrective Justice & 3.5441 & 0.73203 & Agree \\
\hline
\end{tabular}

We can note that the procedural justice came first, followed by interactive justice, distributive justice came secondly and thirdly, and fourthly came corrective justice.

\title{
4.3. The SMA and the Standard Deviations to Sample Responses of Special Functionality
}

Table No. (3) below describes the research variables of the special Job Performance

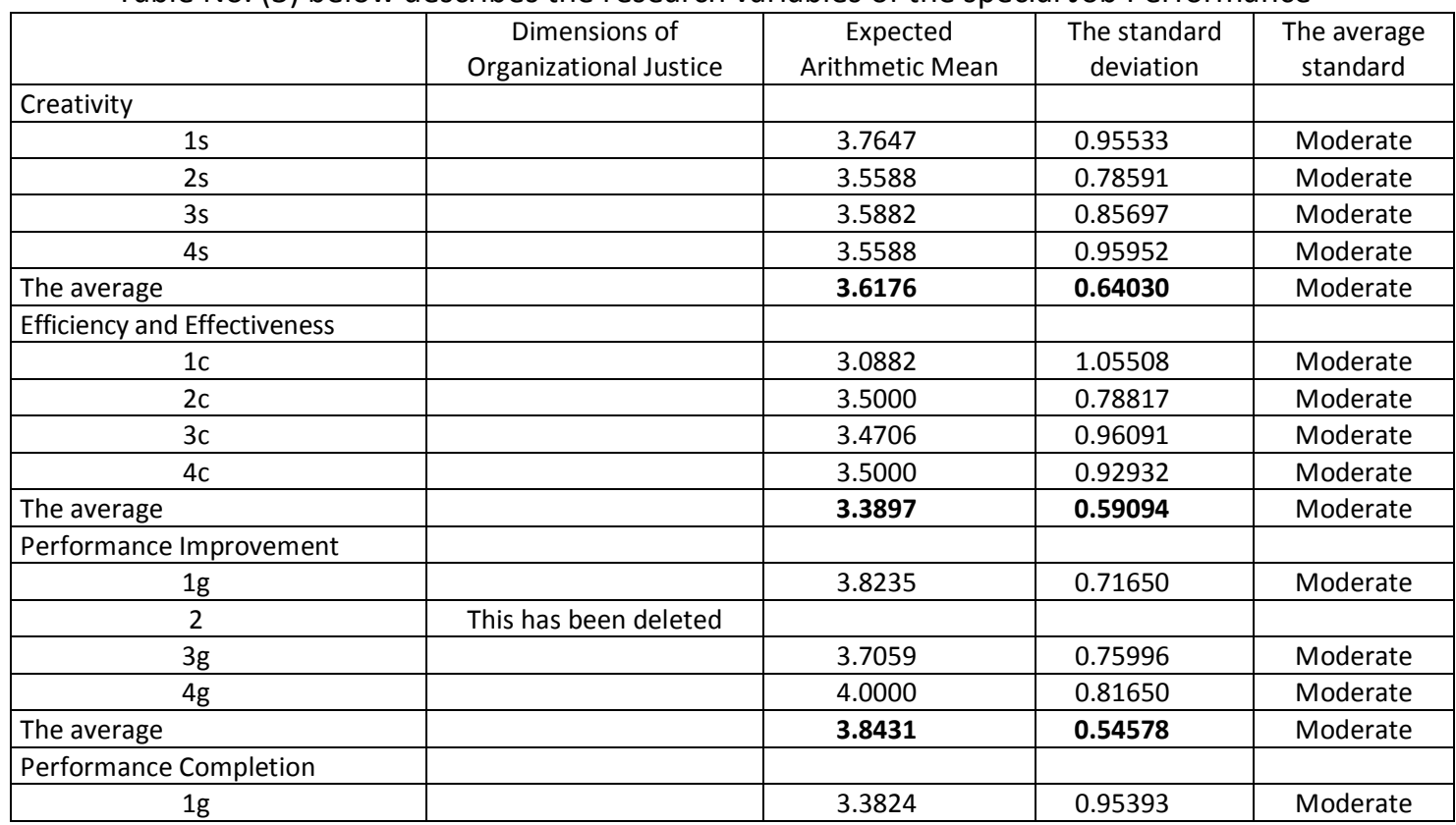




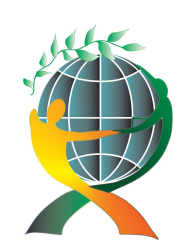

\author{
(online) $=$ ISSN $2285-3642$ \\ ISSN-L = $2285-3642$ \\ Journal of Economic Development, Environment and People \\ Volume 6, Issue 1, 2017
}

URL: http://iedep.spiruharet.ro

e-mail: office jedep@spiruharet.ro

\begin{tabular}{|c|l|l|l|l|}
\hline \multicolumn{1}{|c|}{$2 \mathrm{~g}$} & & 3.6471 & 0.84861 & Moderate \\
\hline 3g & & 3.3824 & 1.07350 & Moderate \\
\hline 4g & & 3.3824 & 1.04489 & Moderate \\
\hline The average & & $\mathbf{3 . 4 4 8 5}$ & $\mathbf{0 . 7 5 3 2 2}$ & Moderate \\
\hline $\begin{array}{l}\text { The main average of the Job } \\
\text { Performance }\end{array}$ & $\mathbf{3 . 6 1 9 5}$ & $\mathbf{0 . 4 9 1 7 3}$ & Moderate \\
\hline
\end{tabular}

Recalling the results of the Table No. ( 3 ) that job performance had SMA in the amount of ( 3.6195) and the standard deviation in the amount of $(0.49173)$ this indicates the homogeneity of the sample answers about the value of covariance level where dimensions came after improving the performance is more homogenous in terms of staff answers as it got the SMA in the amount of (3.8431) and the standard deviation of the normative amount of (0.54578) and to the level of the average (moderate), and the direction of this dimension is (OK) or at the level of the paragraphs the paragraph No. ( 1 ) in this dimension which is (college management seeks the overall and the continuity the development and training of workers for the purpose of improving their performance) is more homogenous, where it got the medium (3.8235) with the standard deviation of (0.71650) and the direction of this paragraph is (OK) at the average level (moderate), and the general trend of the functional performance is ok and to the level of the average (moderate).

\title{
4.4. Testing the First Main Hypothesis
}

Which provides for the moral correlation between the organizational justice and job performance.

$\mathbf{H}_{0}$ : there is no moral relation to link between organizational justice and the functionality

$\mathbf{H}_{1}$ : there is a moral link between organizational justice and job performance.

To stem the assumptions of the following:

- There is a moral correlation between the procedural justice and job performance.

- There is a moral correlation between the interactive justice and job performance.

- There is a correlation between the moral distributive justice and job performance.

- There is a moral correlation between the calendar justice and job performance.

Table 4. The connecting relationship

\begin{tabular}{|c|c|c|c|c|c|c|}
\hline \multicolumn{7}{|c|}{ Correlations } \\
\hline $\begin{array}{c}\text { Organizational } \\
\text { Justice }\end{array}$ & $\begin{array}{c}\text { Corrective } \\
\text { Justice }\end{array}$ & $\begin{array}{c}\text { Distributive } \\
\text { Justice }\end{array}$ & $\begin{array}{c}\text { Interactive } \\
\text { Justice }\end{array}$ & $\begin{array}{c}\text { Procedural } \\
\text { Justice }\end{array}$ & & \\
\hline $0.543^{*}$ & $0.661^{*}$ & 0.289 & 0.315 & 0.306 & $\begin{array}{c}\text { Pearson } \\
\text { Correlation }\end{array}$ & $\begin{array}{c}\text { Job } \\
\text { Performance }\end{array}$ \\
\hline 0.001 & 0 & 0.098 & 0.07 & 0.078 & Sig. (2-tailed) & \\
\hline 34 & 34 & 34 & 34 & 34 & $\mathrm{~N}$ & \\
\hline & & \multicolumn{7}{|c|}{ *. Correlation is significant at the 0.05 level (2-tailed). } \\
\hline
\end{tabular}

Table No. (4) refers to the moral correlation between the organizational justice and the job functionality, where the moral value Pearson parameter equals (0.543) because SIG moral value equals 


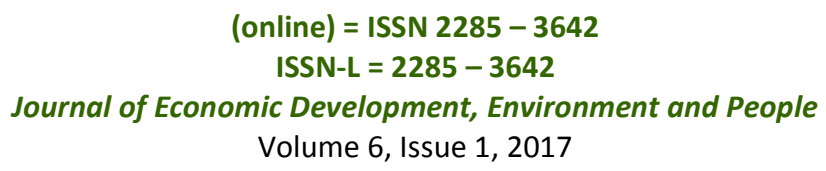

URL: http://iedep.spiruharet.ro

e-mail: office jedep@spiruharet.ro

(0.001), which is less than 0.05 , meaning that the achievement of the first main premise is a moral link between organizational justice and job performance.

At the level of the Sub-hypotheses there is a correlation, where there is a moral link between the Correction justice and the job performance where the value of the link equal (0.661), and the rest of the sub-hypotheses were not moral because the moral value SIG is more than (0.05) leading to the acceptance of the Null Hypothesis, this means the acceptance of the fourth Sub- Hypotheses and the refusal of the first, second and third ones.

\subsection{Testing the Second Main Hypothesis:}

Which indicate that there is a significant moral impact of organizational justice on job performance.

$\mathbf{H}_{0}$ : There is no impact of the organizational justice on job performance.

$\mathbf{H}_{1}$ : there is no impact of the organizational justice on job performance.

Table 5. Variance Analysis

\begin{tabular}{|c|c|c|c|c|c|c|}
\hline \multicolumn{7}{|l|}{ ANOVA $^{b}$} \\
\hline Sig & $\mathrm{F}$ & $\begin{array}{l}\text { Mean } \\
\text { Square }\end{array}$ & Df & $\begin{array}{l}\text { Sum of } \\
\text { Squares }\end{array}$ & \multicolumn{2}{|c|}{ Model } \\
\hline \multirow[t]{5}{*}{$0.001^{\mathrm{a}}$} & 13.401 & 2.355 & 1 & 2.355 & Regression & 1 \\
\hline & & 0.176 & 32 & 5.624 & Residual & \\
\hline & & & 33 & 7.979 & Total & \\
\hline & & & & \multicolumn{3}{|c|}{ a. Predictors: (Constant), X } \\
\hline & & & & \multicolumn{3}{|c|}{ b. Dependent Variable: $Y$} \\
\hline
\end{tabular}

The results of the test of $F$ to the presence of the impact of the organizational justice on job performance set forth in the table No. (5) that the value of calculated $F$ had reached (13.401) at the moral level of (0.05) where the value of P-value equal (0.01), which is less than (0.05) this means the rejection of the Null hypothesis and the acceptance of alternative hypothesis this means that there is the impact of organizational justice on job performance.

Table 6. Organizational Justice Influence on Job Performance

\begin{tabular}{|c|c|c|c|}
\hline & \multicolumn{3}{|c|}{ Job Performance } \\
\hline Variable & $\mathbf{F}$ & $\mathbf{R}^{2}$ & B \\
\hline Certified variable Independent & & & \\
\hline Organizational Justice & 10.652 & 0.295 & 0.546 \\
\hline
\end{tabular}

Table 6. indicated that the value of $R^{2}$ equal (0.295), and this means that the organizational justice had interpreted the value of $(29.5 \%)$ of the changes in the job performance of the values of $B=(0.546)$ which 


\author{
(online) $=$ ISSN $2285-3642$ \\ ISSN-L = $2285-3642$ \\ Journal of Economic Development, Environment and People \\ Volume 6, Issue 1, 2017 \\ URL: http://iedep.spiruharet.ro \\ e-mail: office jedep@spiruharet.ro
}

means the increase in the organizational justice variable of one unit of the standard deviations will lead to an increase in job performance by $54.6 \%$ of the standard deviation.

\title{
5. Results
}

The researchers to the following results:

1. That colleges which are concerned with the means, the decisions and laws that achieve organizational justice to its employees can achieve the highest job performance.

2. Most of the respondents to the questions were males aged between 45-55 with a Master's degree by the length of service of $10-20$ years, showing that the cultural and scientific level of the college staff demonstrates that it belongs to the highly educated class.

3. It turned out that the direction of the sample answers within the axis of the organizational justice is toward (approve), meaning that the sample confirmed the presence of organizational justice exercised by the deanships in the discussed colleges.

4. The interactive justice dimension is the best within this axis of organizational justice and this indicates that the Deanships pay a well attention to interactive justice.

5. There is a moral correlation between the corrective justice and job performance this means that Deanships if it want to achieve a high level of organizational justice should be interested in corrective justice.

6. There is no moral link between (interactive, procedural, and distributional impacts) justice and job performance.

7. It turned out that there is a direct link between the positive organizational justice and job performance.

8. It turned out that there is an impact of organizational justice on job performance and this means that justice played an important role in upgrading the level of organizational performance to the workers.

\section{Recommendations}

Based on the above mentioned conclusions the researchers recommend the following set of recommendations:

1. Deanships are to work harder to support colleges with highly education certificates (doctorate certificate holders in particular) for both of the teaching and administrative staffs.

2. The Deanships in the discussed colleges are to be much interested in all dimensions of the organizational justice to be a reason for the main factor in achieving a high level of job performance.

3. Placing a special interest in the corrective justice being the most influential factor in achieving the functionality of the subordinates.

4. The adoption of the method of dialog with the staff by Deanships, whether they were members of the teaching or the administrative staff to know the reasons Hinder the application the achievement of organizational justice in civil faculties. 


\author{
(online) $=$ ISSN $2285-3642$ \\ ISSN-L = $2285-3642$ \\ Journal of Economic Development, Environment and People \\ Volume 6, Issue 1, 2017 \\ URL: http://iedep.spiruharet.ro \\ e-mail: office jedep@spiruharet.ro
}

5. To continue to strengthen organizational justice in civil colleges as a fundamental value in the organizational culture and continue in its assessment.

\title{
7. References
}

[1] Al-Ajmi, Rashed Shabib. Analysis of the Relationship Between the Organizational Loyalty and a Sense of Justice and the Regulations. Administrative Magazine. 1998, 20 (72), pp. 71-91.

[2] Al Assaf, Hussein Mousa. Career Empowerment of Leadership in Jordanian Universities, and its Relationship to the Organizational Commitment to Stability and Voluntary Career of Members of the Teaching Bodies. not published doctoral dissertation. University of Amman: Amman, Jordan. 2006.

[3] A. Mohsen, T. Muhammad. The Evaluation of Performance, New Entry Points for the New World. Alexandria: The Arab Renaissance Publishing House. 2002.

[4] N. Alhawamda. The Relationship Between the Level of Awareness on the Effectiveness and Fairness of the Corrective System Performance and Functionality of Career Satisfaction and Organizational Loyalty. Organizational Trust and the Staff in the Service Ministries to Jordan. The Administrative Sciences Magazine. 2004, 1 (6), pp. 61-89.

[5] A. A. G. Al-maaita. The Degree of the Exercise of the Directors General Secondary Schools in Jordan Organizational Justice and Their Relationship with the Conduct of the Organizational Citizenship for Their Teachers. not published doctorate thesis. Arabic University of Amman: Amman, Jordan. 2005.

[6] M. Q. Al-qarioti. The Organizational Behavior, the Study of Human Behavior and Individual and Collective in Different Organizations. Amman, Jordan: Dar Al-Shuruq for publishing and distribution. 2000.

[7] S. A. Al Salem. Job Satisfaction for Workers in the University Libraries in the Kingdom of Saudi Arabia. Riyadh: King Fahd's National Library. 1997.

[8] N. A. Alqatawnah. The Impact of the Organizational Justice in the Organizational Loyalty. not published master dissertation. Karak: Moata University. 2003.

[9] H. A. R. S Altaweel. Education Management and Organizational Behavior, The Behavior of Individuals and Groups in the Systems. (I1). Amman: Dar Wael for printing and publishing. 2001.

[10] S. M. Altaheeh, M. Ali. Hussein. The Relationship Between the Organizational Structure and the Extent of the Realization of Justice Regulations. Administrative Magazine. 2003, 32 (25), pp. 81-108.

[11] L. M. Assaf. The Sources of the Authority of the Directors Secondary Schools in Jordan and its Relationship with the Status of Reset Anger of Achievement for Teachers in Those Schools. not published doctoral dissertation. Amman, Jordan: Arabic University of Amman for High Studies. 2005.

[12] M. A. L. Khalifa. The Determinants of the Behavior of the Organizational Volunteering in Public Organizations, Analytical Study in the Field, in the Light of Some of the Modern Behavioral Theories. Arab Magazine of Administrative Sciences. 1997, 5 (3), pp.64-78.

[13] R. Hassan. Organizational Behavior of the Contemporary World. Alexandria: University Publishing House. 2002.

[14] S. A. Sultan. Organizational Justice to the Chairmen of the Academic Departments in Jordanian Universities and Their Relationship with Job Satisfaction, and Loyalty to the Organizational Structure of the Members of the 


\author{
(online) $=$ ISSN $2285-3642$ \\ ISSN-L = 2285 - 3642 \\ Journal of Economic Development, Environment and People \\ Volume 6, Issue 1, 2017 \\ URL: http://iedep.spiruharet.ro \\ e-mail: office jedep@spiruharet.ro
}

Teaching Staff. not published doctorate thesis. Amman, Jordan: Arabic University of Amman. 2006.

[15] K. A. S. Saraireh. Organizational Uniformity of Members of the Teaching Staff in Jordanian Hashemite Universities and its Relationship to their Feelings of Security and Their Career Performance. not published doctorate thesis. Amman, Jordan: Arabic University of Amman. 2005.

[16] A. Sizlaqi, M. J. Wallace Mark. Organizational Behavior and Performance. Interpreted by Jaafar Abu al-Qasem Ahmad. Riyadh: The Institute of Public Administration. 1991, 8 (5), pp. 227.

[17] T.V. Rao. Performance management and Appraisal system $1^{\text {st }}$ ed. New Delhi: Sage Publications. 2004.

[18] M. Coloski. An Instrument to Measure Perceptions of Organizational Justice of Middle Schools. Dissertation Abstract International. 2003, 63 (8), pp. 27-55.

[19] R. Koopman. The Relation Ship Between Perceived Organizational Justice and Organizational Citizen Ship Behavior. USA. 2003.

[20] M. Cassandra, M. Surles. Factors Associated with Job Satisfaction and Job Related Stress. DAL-A. 2002, 63 (03), pp. 533.

[21] R.J. Schmiesing. Factors to Ohio State University Extension Agents Perceptions of Organizational Justice and Job Satisfaction. Dissertation Abstract International. 2002, 63 (4), p. 1517.

[22] N. S. Towajj. Exploring the Relationship Between Excellence in Job Performance and Excellence in Quality of Life. Journal Personal Selling. 2000, 21 (5), pp. 97-122.

[23] L. Byars, L. Rue, W. Leslive. Human Resource Management $5^{\text {th }}$ ed. New York: Irwin MCGRAW Hill, Companies, Inc. 1997.

[24] B. Niehoff, R. Moorman. Justice as Mediator of the Relation Ship Between Methods of Monitoring and Organizational Citizen Ship Behavior. Academy of Management Journal. 1993, 35 (3), pp. 527-556. 